\title{
Læringsorienterede kursusdesign
}

Anmeldt af Julie Borup Jensen, konstitueret lektor, Institut for Loering og Filosofi, Aalborg Universitet.

Signe Skov med bidrag af Hanne Leth Andersen

Samfundslitteratur, 2015

102 sider

ISBN 9788759322062

Bogen Laeringsorienterede kursusdesign er udformet som en håndbog. Dens indhold er relevant for alle, der har ansvar for og interesse i udvikling af uddannelse på universiteter og henvender sig til undervisere, studieledere og uddannelsesledere ved universitetsuddannelserne.

Bogen lægger i det første kapitel ud med kortfattet at opridse det samfundsmæssige landskab, som moderne universitetsuddannelse er en del af. I den forbindelse beskrives en relevant og genkendelig række af udfordringer, der har betydning for såvel udvikling af uddannelse, kursusplanlægning og planlægning og gennemførelse af undervisning. Denne tråd følges op i kapitel 4, hvor Hanne Leth Andersen bidrager med overvejelser over eksamens- og vurderingsmetoder og deres relevans for intern og ekstern kvalitetsudvikling.

Resten af de ti kapitler er viet til at fremstille mulige tilgange og metoder som løsninger på uddannelses- og undervisningsmæssige udfordringer ud fra nyeste forskning inden for uddannelse og universitetspædagogik.

I de enkelte kapitler tages der udgangspunkt i et særligt tema inden for uddannelses- og undervisningsdesign, hvor udfordringer og løsninger danner rammen for de enkelte temaer. Følgende generelle temaer behandles:

- Formulering af studieordninger

- Formulering af læringsmål

- Valg af eksamensformer (og sammenhæng til læringsmål samt viden, færdigheder og kompetencer)

- Evaluering af undervisning

Enkelte kapitler dykker ned i mere specifikke temaer som

- Særlige omstændigheder ved skriftlig eksamen, herunder vejledning og feedback

- Undervisningsformer og deltageraktivering. 
Bogen afsluttes med en kortfattet vejledning til kriterier for, hvilke beslutninger der skal tages ved udformning af studieordninger.

\section{Systematisk og overskuelig}

Overordnet set er det bogens force, at den forholder sig systematisk og overskueligt til en række af de læringsmæssige og undervisningsmæssige problemstillinger, som enhver, der beskæftiger sig med uddannelse, på et tidspunkt vil opleve. Det gør, at en bred målgruppe kan have udbytte af at læse bogen. Det gælder såvel den uerfarne underviser, der for første gang står for at skulle forholde sig til at undervise uden måske at have den store viden eller erfaring med pædagogiske aktiviteter, som den erfarne udvikler af kurser og studieordninger, der oplever, at de samfundsmæssige og politiske forandringer gør det nødvendigt at forandre og udvikle rammer og progression i uddannelserne med basis i nyeste forskning.

\section{Tips og tricks}

En af bogens største styrker er de mange, kortfattede og helt konkrete tips til studieledere og undervisere, der indgår rundt omkring i teksten. Idéen med at give praktisk råd og vejledning til den helt konkrete formulering af studieordninger og studiemål, konkret design af kurser og konkret planlægning af undervisning, fungerer godt og hensigtsmæssigt i forhold til bogens sigte.

\section{Videregående uddannelse generelt}

Ovenstående styrker gør også bogen velegnet som inspirationsmateriale ud over en universitetskontekst. Andre videregående uddannelser vil også kunne profitere af bogens systematiske, velunderbyggede og samtidig meget praktiske anvisninger og gode råd. Ikke mindst fordi også udvikling af studiemål og eksamensformer i forbindelse med praktik berøres, om end det er kort. 